\title{
Varied shoot growth in rice plants across different developmental stages under induced flooding
}

\author{
Pratyasha Samanta ${ }^{1}$, Abhra Chakrabarti ${ }^{2} \&$ Narottam Dey ${ }^{1^{*}}$ \\ ${ }^{1}$ Rice Biotechnology laboratory, Department of Biotechnology, Visva-Bharati, Santiniketan 731 235, India \\ ${ }^{2}$ Ausgram Development Block, Govt. of West Bengal, India \\ *Email: narottam.dey@visva-bharati.ac.in
}

\section{ARTICLE HISTORY}

Received: 01 April 2021

Accepted: 19 June 2021

Available online: 14 July 2021

\section{KEYWORDS}

submergence avoidance

rice landraces

morpho-physiological traits

stage-specific flood tolerance

\section{ABSTRACT}

All the modern high yielding rice varieties precariously respond to flooding, although a number of landraces are tolerant to wide range of flooding with penalty of low yield. Stage-specific flood tolerance experiment was performed at three different conditions for three different growth stages from germination to vegetative stage for five such selected landraces, along with a flood-resistant quiescent variety (FR13A), a sensitive line (IR42), an improved cultivar (Swarna) and one Sub1 loci introgressed improved line (Swarna-Sub1). Different morpho-physiological traits at each stage were observed and genotypes were evaluated by these quantifiable traits to understand their underwater performance. All the studied landraces represented strong seed germination and faster coleoptile elongation than FR13A, Swarna and Swarna-Sub1 under water. At early seedling stage var. Kumrogarh embraced with highest number of seedlings with leaves and extended greater leaf portion above the water. Shoot elongation associated with internodal and petiole/blade elongation and well developed aerenchyma tissue facilitated vegetative tissues to survive. In this stage, Kumrogarh had highest plant height but Bakui had highest internodal length which indicated that kumrogarh might have the greater leaf sheath or blade elongation up to day 21 and also smaller increase (\%) in air cavity formation at day 21 which made the stem to be upright devoid of lodging. All these results indicated that the studied landraces are the potential resources for submergence avoiding response for all the stages and should be elaborately investigated for future breeding programme. The rice line kumrogarh may be one of the potent traditional rice which can withstand all sorts of submergence by virtue of all the stage-specific attributes under submergence stress.

\section{Introduction}

Rice is one of the most amenable food crops for billions of people of the world. It covers a wide range of enormous diversity and plasticity in hydrological habitats, ranging from aerobic uplands to anaerobic flooded and low land areas to even deeply flooded agro-ecosystems. In South and South-East Asia about 15 Mha of low land areas is largely affected by flooding (1).

Rainfed lowland and deep water rice are actually accounting for 50 Mha of total rice area $(2,3)$ and providing only $25 \%$ of global rice production because of abrupt changes of environmental conditions (4). Thus, flood imparts huge losses in rice production during rainy season in tropical Asian countries (5).

Although rice is semi-aquatic species, its sensitivity to various types of flooding stress varies with the genotype, growth and developmental stage, duration and depth of flooding and floodwater conditions (5-8) depending on rice growing agroecosystems (1). Mechanisms of tolerance to submergence in one stage may not match to other stage, potent seed germination (9) and coleoptiles growth $(6,10)$ are required for early seedling growth, whereas rapid shoot elongation with use of carbohydrate or inactivation of shoot elongation contrastingly occur during vegetative growth stage (11).

Flooded and water-logged soils create hypoxic or anoxic condition but rice landraces and wild types germinate and elongate coleoptiles faster under submergence- the unique phenomenon is termed as anaerobic germination (AG) and ability to have such property is termed as anaerobic germination potential (12). In the flood prone areas crop establishment remains a major constraint after seed sowing due to heavy rainfall or uneven fields $(1,9)$. Farmers shift crop establishment from transplanting to direct seeding for a large scale benefits like, cost 
effectiveness as it reduces labour wages for manual or mechanical weeding and prevent use of hazardous chemical for controlling weeds (13), reduce excessive use of water needed for land preparation before transplanting, shorten harvest time (14) which further enhance productivity and resource usage (11). Seeds with ability for anaerobic germination are now opted for direct seeding as they have vigorous germination capacity and endure early flooding in comparison with weeds. This will permit the rice seedling to be established in the soil before the weed suppress the growth (15) and made it best cultural practise for weed control without creating any hazards to the environment (11).

Not withstanding occurrence of flooding at germination stage, it may encounter during early growth stage after establishment to the soil, even after that, at vegetative stage and tolerance achieved either of mechanisms by faster coleoptile elongation or internodal elongation or by inactivation of internodal elongation. Flood tolerance at each stage is associated with several quantifiable traits apparently visible to the naked eye. Vegetative stage flooding incurs two different strategies, first one is deep water flooding and second one is flash flooding. Deep water flooding lasts for longer duration (1several months) with rising water level from 0.5-1 meter promotes rapid internodal elongation to keep its leaf tip beyond the water surface to continue photosynthesis (16). In contrast to that, complete submergence persists for 10-14 days with growth remains quiescent and renew after flood water recedes (17). Apart from that, some anatomical adaptation also co-exists at vegetative stage to continue respiration under water. Well developed interconnected aerenchyma tissue facilitates $\mathrm{O}_{2}$ diffusion from root to the leaf tip as the plants experienced anoxic or hypoxic stress under water (13) and makes the plant floating at this stage. But at the germinating and early seedling stages aerenchyma tissues neither well-developed nor underwater photosynthesis occurs to serve $\mathrm{O}_{2}$ (11). Thus coleoptile elongation and seedling emergence above the water surface occurs during germination and early growth stages respectively (18) as extended coleoptile enables the seedlings to make contact with the atmosphere to achieve $\mathrm{O}_{2}$ (19) and as soon as seedling reaches to more aerated zones, aerenchyma tissue forms to supply oxygen for the submerged plant parts, especially to roots - as stem starts snorkeling $(20,21)$. The aim of this study was to assess the differential responses of nine rice genotypes at three different growth stages under water. Evaluation of genotypes at germination and post germination early seedling stage (at different depth and durations) demonstrates their capability to adapt direct-seeding system. Similarly, tolerance at vegetative stage reflects their underwater behavior during submergence and post submergence recovery. We herein gather adequate knowledge about the key traits associated with the flood tolerance behavior at each stage and compared. This will reflect holistic performance in terms of morpho-physiology of the used genotypes and identify tolerant varieties for

Table 1. Experimental details include stage, location, water depth, duration and measurements

\begin{tabular}{llllll}
\hline Experiment & Stage & Location & Water depth & Duration & Measurements \\
\hline $\begin{array}{l}\text { Anaerohic } \\
\text { germination potential }\end{array}$ & Germination & $\begin{array}{l}\text { Laboratory, plastic } \\
\text { glass }\end{array}$ & $5 \mathrm{~cm}$ & 7 days & $\begin{array}{l}\text { Germination\%, coleoptile length, } \\
\text { root length }\end{array}$ \\
\hline $\begin{array}{l}\text { Emergence\% } \\
\text { determination }\end{array}$ & Early seedling & $\begin{array}{l}\text { Plant growth } \\
\text { chamber, plastic } \\
\text { glass, tray }\end{array}$ & $\begin{array}{l}6 \mathrm{~cm} \text { and } 30 \\
\mathrm{~cm}\end{array}$ & 7,14 days & $\begin{array}{l}\text { Plant height, emergence\%, total no. } \\
\text { Of leaves, no. Of leaves above water, } \\
\text { leaf portion above water }\end{array}$ \\
\hline Shoot elongation & Vegetative & $\begin{array}{l}\text { Natural condition, } \\
\text { water tank }\end{array}$ & $90 \mathrm{~cm}$ & 7.14 .21 days & Plant height, internode length \\
\hline
\end{tabular}

Table 2. Detailed agro-morphological characteristics of the studied genotypes

\begin{tabular}{|c|c|c|}
\hline Name of variety & Accession No. & Morphological characteristics \\
\hline FR13A & VB69 & $\begin{array}{l}\text { Grain medium long and bold with distinct awn, Kernel reddish brown in color, reported from lowland } \\
\text { rice fields of Odisha. }\end{array}$ \\
\hline IR42 & VB451 & $\begin{array}{l}\text { Grain slender, decorticated grain color white, presently grown in irrigated, rainfed upland or lowland } \\
\text { rice fields. }\end{array}$ \\
\hline Swarna & VB38 & $\begin{array}{l}\text { Grain is medium-slender, high yielding improved line susceptible to flash flood, presently grown in } \\
\text { high rainfed land. }\end{array}$ \\
\hline Swarna-Sub1 & VB449 & $\begin{array}{l}\text { Grain slender small, white kernel, hybrid rice genotype in which flood tolerant allele of Sub1A of a } \\
\text { typical submergence tolerant genotype FR13A has been incorporated through conventional breeding. } \\
\text { Presently grown in low land rice fields. }\end{array}$ \\
\hline Bhimshal & VB490 & $\begin{array}{l}\text { Aromatic, long bold grain with yellowish brown awn, kernel white, basal Leaf sheath color purple } \\
\text { lines, ligule is acute and white colored, anthocyanin present in leaf sheath and node, stigma color } \\
\text { purple, panicle drooping, brown colored awn is present, grown as lowland rice cultivar. }\end{array}$ \\
\hline Kaliray & VB484 & $\begin{array}{l}\text { Long slender grain, color of the lemma and palea black furrow on straw, anthocyanin pigmentation on } \\
\text { internode leaf tip, basal leaf sheath color green, awn present partly and colored straw, caryopsis color } \\
\text { light red, stigma white, aroma absent,grown as lowland rice cultivar. }\end{array}$ \\
\hline Kumrogarh & VB492 & $\begin{array}{l}\text { Long slender grain, kernel is red in appearance, anthocyanin pigmentation found in stigma basal leaf } \\
\text { sheath color light purple, coleoptile color purple line, anthocyanin present on leaf margin, leaf sheath, } \\
\text { stigma purple, no anthocyanin in stem node, panicle deflexed, awn absent, in red color caryopsis } \\
\text { chalky belly present, aroma absent,grown as lowland rice cultivar. }\end{array}$ \\
\hline Bakui & VB506 & $\begin{array}{l}\text { Grain long slender, light purple coloration on auricle, basal leaf sheath color green, acute white colored } \\
\text { ligule, anthocyanin absent in node and leaf sheath, stigma color white, awn color straw, caryopsis color } \\
\text { light red, panicle drooping,grown as lowland rice cultivar. }\end{array}$ \\
\hline Megi & VB512 & $\begin{array}{l}\text { Grain is long bold, color of lemma palea white, color of endosperm white, stigma white in color, basal } \\
\text { leaf sheath color green, anthocyanin is absent in leaf and stem, ligule acute and white,awn } \\
\text { absent,aroma absent,grown as lowland rice cultivar. }\end{array}$ \\
\hline
\end{tabular}


designing effective breeding strategies for the molecular breeders.

\section{Materials and Methods}

\section{Plant Materials and Experimental Design}

Nine different rice genotypes, namely FR13A, IR42, Swarna, Swarna-Sub1 and five landraces Kaliray, Bhimshal, Kumrogarh, Bakui, Megi with variable response to submergence were selected from preliminary screening and evaluated at three different stages with different experimental set up demonstrated in Table 1. Agro-morphological features of these lines were elaborately described in Table 2. The two lines, FR13A and IR42 were included as positive and negative check lines. Swarna, an improved line commonly grown in high rainfed land and its Sub1 loci introgressed lines (Swarna-Sub1) which is grown as Shallow low land line in South Bengal were included for comparative study. Four separate experiments were conducted to study the physiological performance at different growth stages of the studied lines.

In experiment-I, determination of germination potential at anaerobic condition was performed under laboratory condition at room temperature (Fig. 1). 20 seeds of each variety were surface sterilized and after vigorous washing these were allowed to germinate in tissue paper soaked with water in $10 \mathrm{~cm}$ small plastic glass. Another replica set was filled with $8 \mathrm{~cm}$ water (mixture of equal quantity of water and Hoagland solution) to make the environment anaerobic. Two sets of each variety was monitored for 7 days and water level was maintained at the same height for test sets and water was also applied to the control set as well to keep the cotton wet till 7 days. After 7 days total number of seeds, number of seeds germinated, coleoptiles and root length were measured in both cases. Germination percentage was calculated by the total number of seeds germinated by the total number of seeds used $(n=20)$. Length of emerging roots and coleoptiles of anaerobic germinated seeds were measured on a glass plate with mounted graph paper and control seeds were measured by scale.

In experiment II (Fig. 2), 10 healthy seeds of all nine rice genotypes were sown in small plastic jars (5 $\mathrm{cm} \times 4 \mathrm{~cm}$ ) at about $1 \mathrm{~cm}$ deeper into the soil and allowed to germinate by keeping in plastic tray of 32 $\mathrm{cm} \times 25 \mathrm{~cm} \times 10 \mathrm{~cm}$ in plant growth chamber at about $34{ }^{\circ} \mathrm{C}$. After 4 days, number of germinated seeds was calculated and tray was flooded with water up to the edge (6 cm soil+ $4 \mathrm{~cm}$ water). Number of seedlings, emerging above the water was monitored on the very next day and 3 out of 7 germinated seedlings of IR42 and 6 out of 10 germinated seedlings of Kumrogarh were escaped out of the water. For this, screening some features were observed i.e. seedling height, number of seedlings above water, number of leaves above water, total number of leaves, length of the seedling portion above water (13) was measured for each of the 9 varieties on day 7 . After the measurement, plastic tray containing seedlings was re-submerged with $30 \mathrm{~cm}$ water depth in concrete tank on the same day $\left(7^{\text {th }}\right)$. After 14 days tray was removed from the tank and all the plants were found to be lodged. The only parameter to be measured was the seedling height and no seedlings found to be emerged beyond the water surface except kumrogarh, 6 seedlings were above the water surface. Another replica set was watered normally until the end of experiment, treated as, control set the relevant features recorded for control sets weremeasurement for seedling height, total number of seedlings and total number of leaves.

In experiment III, after pretreatment of 20 healthy matured seeds of each genotype, allowed to germinate on cotton soaked with water. On $10^{\text {th }}$ day, the pre-germinated seedlings were transplanted in 11 volume small plastic pots having finely grounded field soil followed by normal watering. Seedlings were allowed to grow under natural conditions in triplicates. 28 days old seedling triplicates with uniform growth was submerged completely in $90 \mathrm{~cm}$ water tank filled with tap water (Fig. 3). Control set was maintained in open air and watered regularly. After 7, 14 and 21 days of submergence treatment, the dedicated replica pots were taken out from tank and measurement of plant height and internode length was done as well. Plant height was measured from base of the stem to the longest leaf tip and the length between the first and second node was treated as internode length.

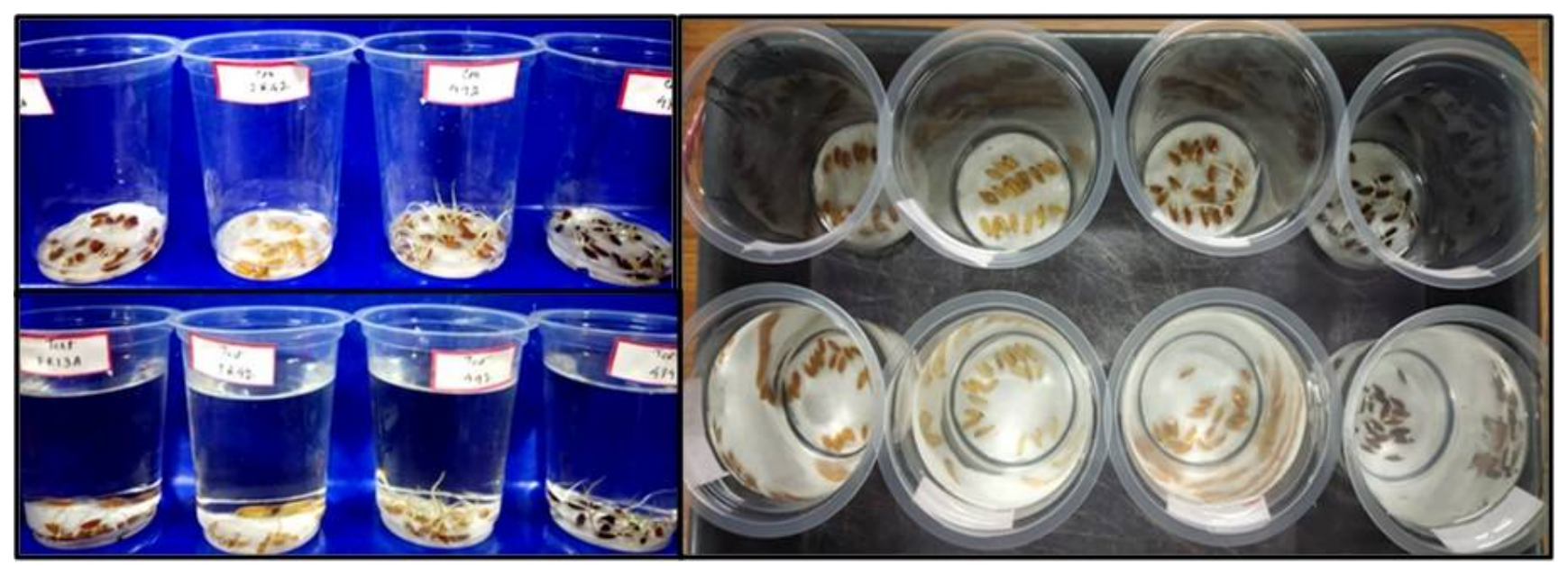

Fig. 1. Determination of germination percentage and anaerobic germination potential (AGP). 


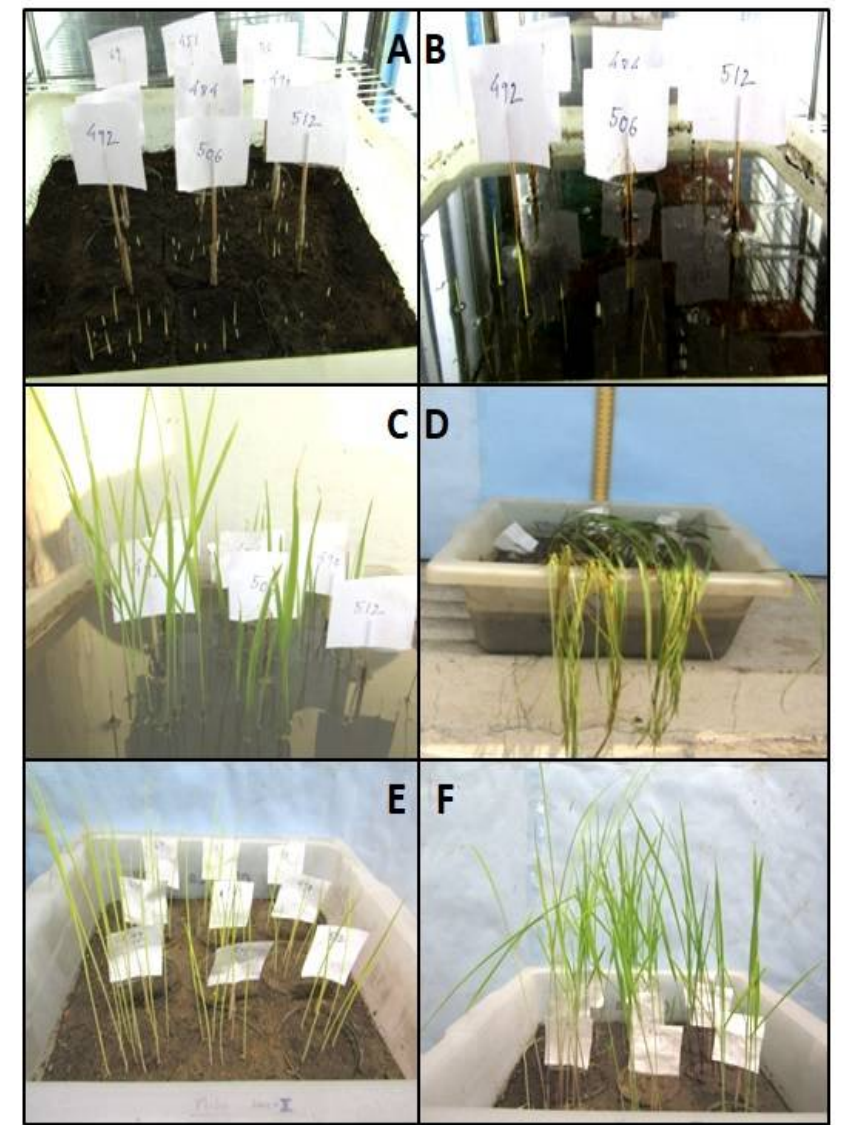

Fig. 2. Response of rice at early seedling stage at different depth and duration of flooding in comparison to control set. A) Germination occurred after 4 days of sowing. B) After flooding for $6 \mathrm{~cm}$ water depth on next day, first appearance of seedling emergence occur on the $6^{\text {th }}$ day for var. Kumrogarh and IR 42 . C) All varieties showed seedling emergence. D) On day 7 plastic tray was submerged at $30 \mathrm{~cm}$ water depth in the water tank for 7 days,at $14^{\text {th }}$ day seedlings found to be lodged on desubmergence. E) Control plants for 7 days. F) Control plants for 14 days.
Sections of stressed samples were compared with their control set and the data was recorded as average length and breadth of air spaces (five readings). Number of air spaces was calculated and total area was determined accordingly in five landraces selected from their physiological performance with additional to two checks FR13A and IR42.

\section{Statistical Analysis}

Data from each stage-specific experiment were recorded in three replications for each parameter both for control and stress conditions and subjected to t-Test for Two-samples assuming unequal variances using Microsoft Excel 2007 at 5\% significance level to test the data for significance. Values in asterisks $(*)$ are considered as significant at $5 \%(p>=0.05)$ for different parameters for each stage.

\section{Results}

To assess the differential response of anaerobic germination of nine diverse rice genotypes two important screening features were used to identify the tolerant genotype- anaerobic germination potential (AGP) and coleoptile length determination as fast germination and coleoptile elongation help to emerge above the water for survival $(9,22)$. If we view (Fig. 4) the percent germination it was found used landraces had more or less similar anaerobic germination potential as in control except Kaliray. But germination rate varied in case of FR13A, IR42, Swarna and Swarna-Sub1 in con vs test. It was found coleoptile length strikingly varied among all the genotypes but commonly anaerobic condition restrainted the coleoptile growth (Fig. 5a).

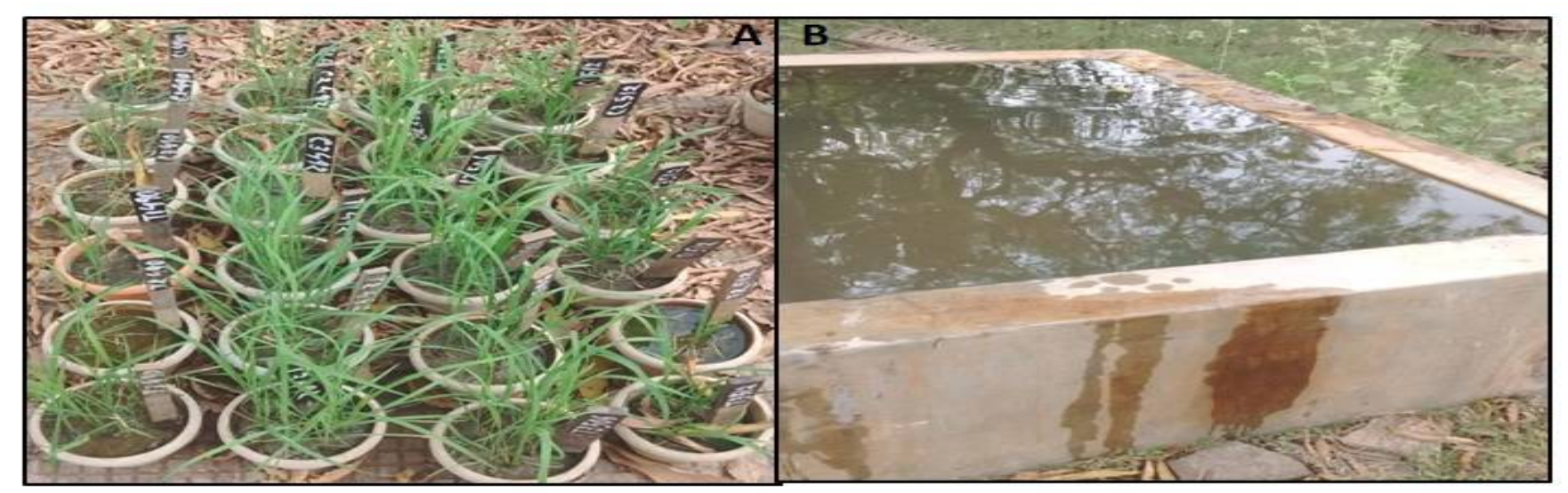

Fig. 3. Vegetative stage screening. A) Control sets maintained in air. B) Test sets transfer to the water tank.

\section{Anatomical Study}

To visualize the interconnected air-cavities required for proper aeration under submergence stress in the inter-nodal portion of seedlings, thin cross sections were prepared from treated and non-treated plants of three phases (7, 14 and 21 days) and viewed under compound microscope (Model OLYMPUS CX21i) in 40x magnification and full section was photographed in $4 \mathrm{x}$ magnification. Transverse sections of $1 \mathrm{st}$ internode were taken on a slide and stained with $1 \%$ safranin for 20 seconds. Excess strain from the samples was removed by $50 \%$ ethanol treatment.
Kumrogarh had the highest coleoptile growth under control and kaliray had the highest under water. Whereas root length drastically reduced under water for all the genotypes, but landraces showed slightly higher length in respect of negligible growth in FR13A, IR42, Swarna and Swarna-Sub1 (Fig. 5b). Bhimshal has the highest increment in root length.

Experiment II dealt with some salient features at different water depth for different durations are graphically presented in Fig. 6 (a, b, c, d, e) respectively. Kumrogarh had the highest plant height both in control and test conditions at two different 
depths and durations of water (Fig. 7a). Number of seedlings above the $6 \mathrm{~cm}$ water level was equal for Kaliray and Kumrogarh that was the highest one, but at day 14 with $30 \mathrm{~cm}$ water depth Kumrogarh was the only candidate to overcome the stress outstandingly. For the parameters like number of leaves and leaf portion above the water surface at varied durations and depths Kumrogarh performed the best amongst all (Fig. 6d, 6e).

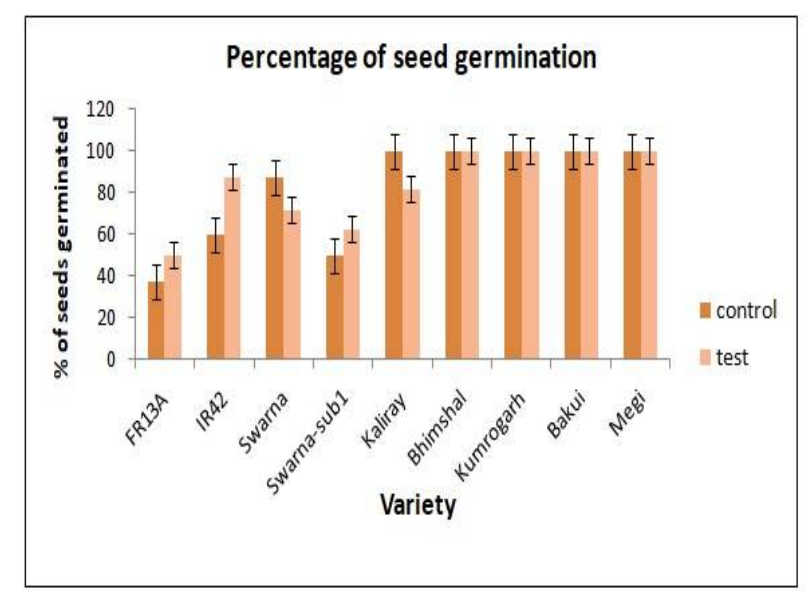

Fig. 4. Percentage of seeds germinated under water in comparison to control for all the genotypes.

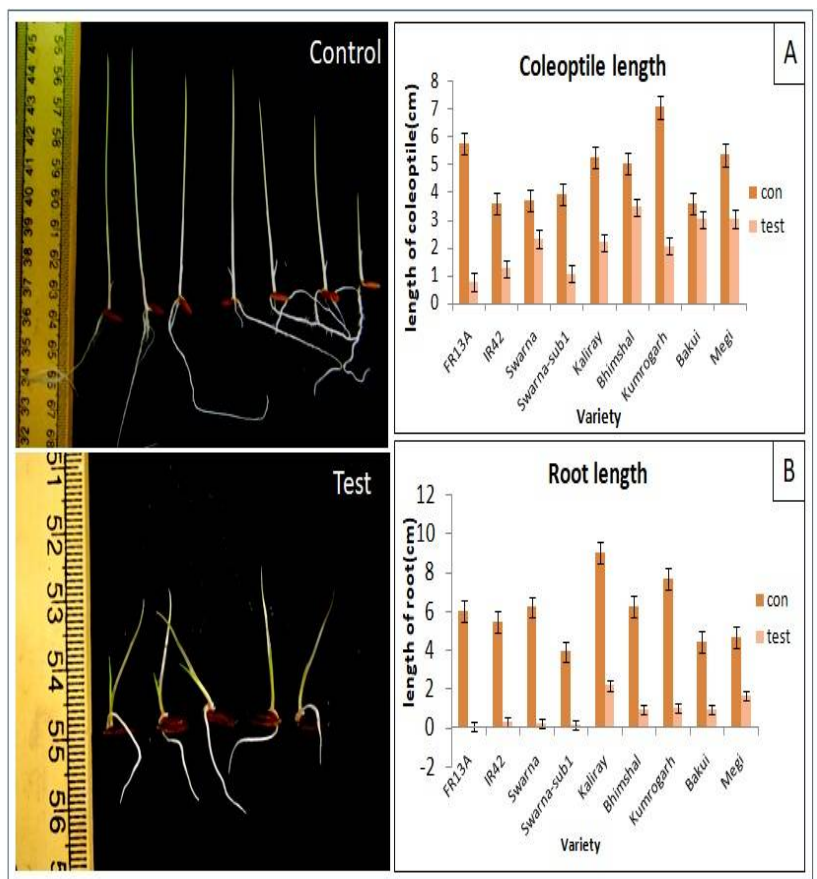

Fig. 5. Coleoptile length (A) and root length (B) of germinated seeds of nine genotypes under water for 7 days at $8 \mathrm{~cm}$ depth and at control conditions.

Screening at vegetative stage revealed that there was a progressive increase in plant height under stress for all the accessions except FR13A (Fig. 7a). Not only plant height internode length also increased with time for all the genotypes but Bakui had this continuity at the highest level (Fig. 7b).

All different parameters specific to each stage were elaborately described in Supplementary Table 1.

\section{Anatomical Study}

Anatomical study in the form of aerenchyma tissue development in the internodal region under stress was carried out in seven selected varieties (var. FR13A, IR42, Kaliray, Bhimshal, Kumrogarh, Bakui and Megi) and compared. The differential air cavity formation (Fig. 8) under submerged condition revealed that on 7th day of submergence percent increase of area of air cavity formation was found in Var. IR42, Kaliray, Kumrogarh, Bakui, Megi of which Megi is being the highest and IR42 is the lowest one amongst all. Tolerant genotype FR13A and sensitive check IR42 show increase in aerenchyma tissue formation in 14 days along with Var. Kumrogarh and Bhimshal. Kumrogarh is being the highest to be ranked. Further, 21st day pictures show that Var. Kaliray, Kumrogarh and Megi developed more aerenchyma tissue in comparison to others. Among these three, Kumrogarh was found to develop least amount of air vacuoles and Megi to be the highest one. Rice lines showing differential response in terms of elongation growth under complete submergence were selected to dissect anatomically and their percentage (\%) of increase in air cavity formation in comparison to control in three phases (7th day, 14th day and 21st day) is presented in Fig. 9.

By analyzing all the data on morpho-physio performance Kumrogarh is considered as most suitable genotype amongst all the studied genotypes under deep flooded condition.

\section{Statistical Analysis}

Result of statistical analysis is presented in Supplementary Table 2.

\section{Discussion}

To cope with the adversities of submerged or waterlogged conditions rice plants develop some adaptive strategies and the mechanisms underpinning the tolerance response varies from stage to stage. We herein observe the morphological features that influence the survival ranging from germination to vegetative stage under deep water submergence.

In this study, all the landraces well performed under water by prompt germination which is a prerequisite for direct-seeded rice ecosystem to combat the weed species germinating with rice (15). Thus, controlled flooding can be used to suppress weeds instead of hazardous herbicide to the environment. Vigorous growth of root and coleoptile demarcated the tolerant genotypes (9), here the landraces.

Flooding tolerance to early growth stages necessitates the survival under early flooding immediately after direct seeding. Emergence percentage i.e. the number of seedlings above the water surface reflects the survival rate (23). Our study deals with determination of emergence percentage at two different flood regimes revealed that Kumrogarh had the highest seedlings to come out of the water. In terms of number of leaves and leaf portion above the water (two selectable traits at 


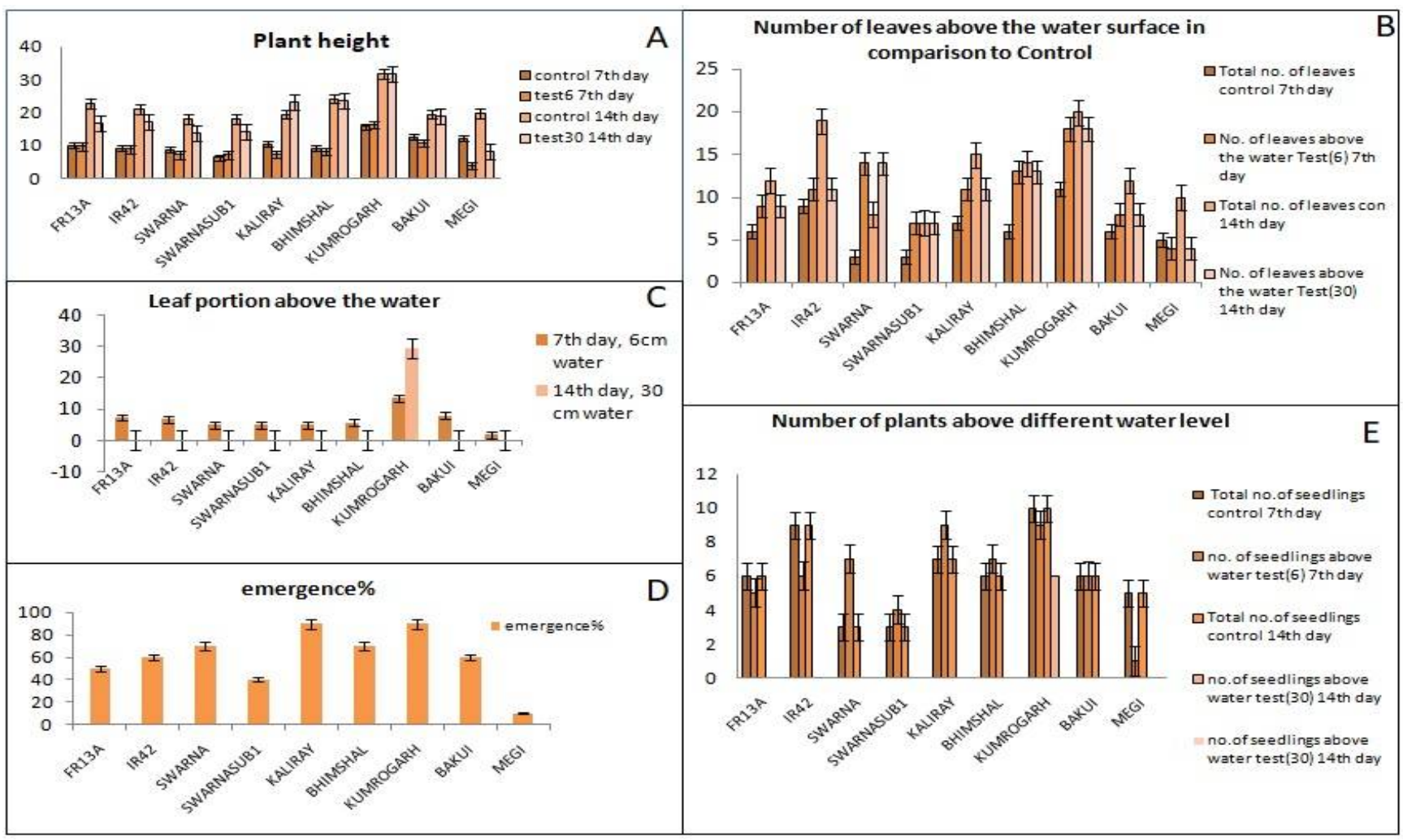

Fig. 6. Effect of flooding on different depths) $6 \mathrm{~cm}$ and $30 \mathrm{~cm}$ ) and duration (7 and 14 days) of water at early seedling stage.

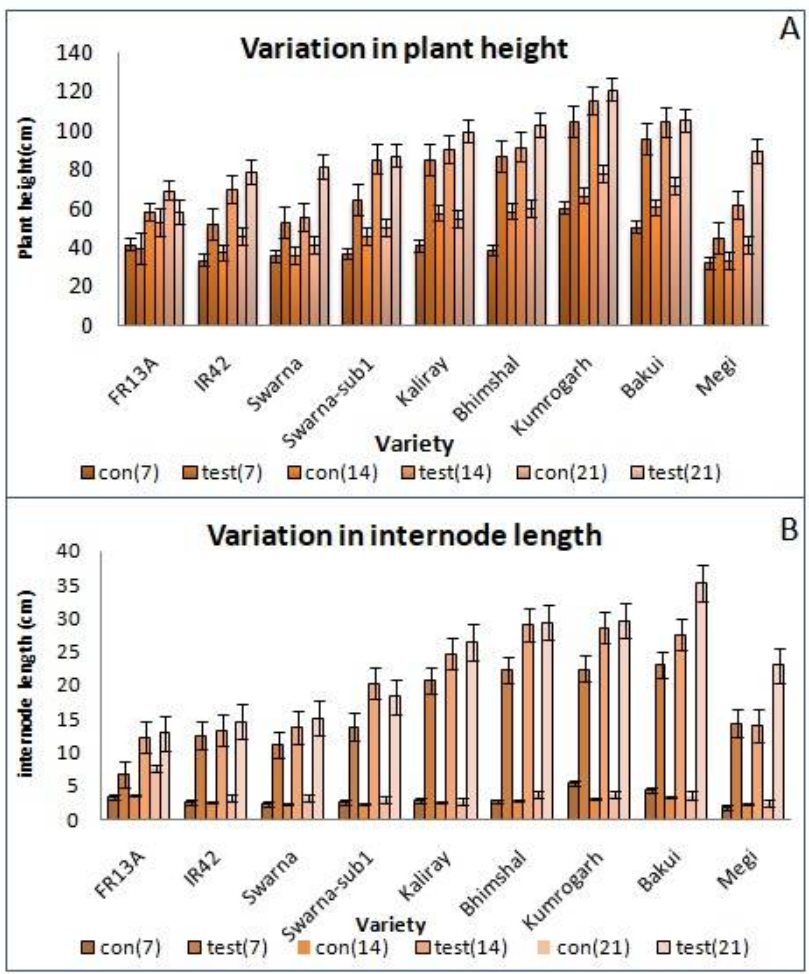

Fig. 7. Effect of flooding on plant height (A) and internode length (B) of the studied genotypes at vegetative stage.

early stage) at varied flooding depth and duration Kumrogarh showed the satisfactory performance.

At last stage of screening i.e. at vegetative stage kumrogarh procure the highest plant height which was not necessarily because of internode elongation as Bakui had the highest internode length. Thus, it may be hypothesize that leaf petiole or blade elongation was greater in Kumrogarh than Bakui as

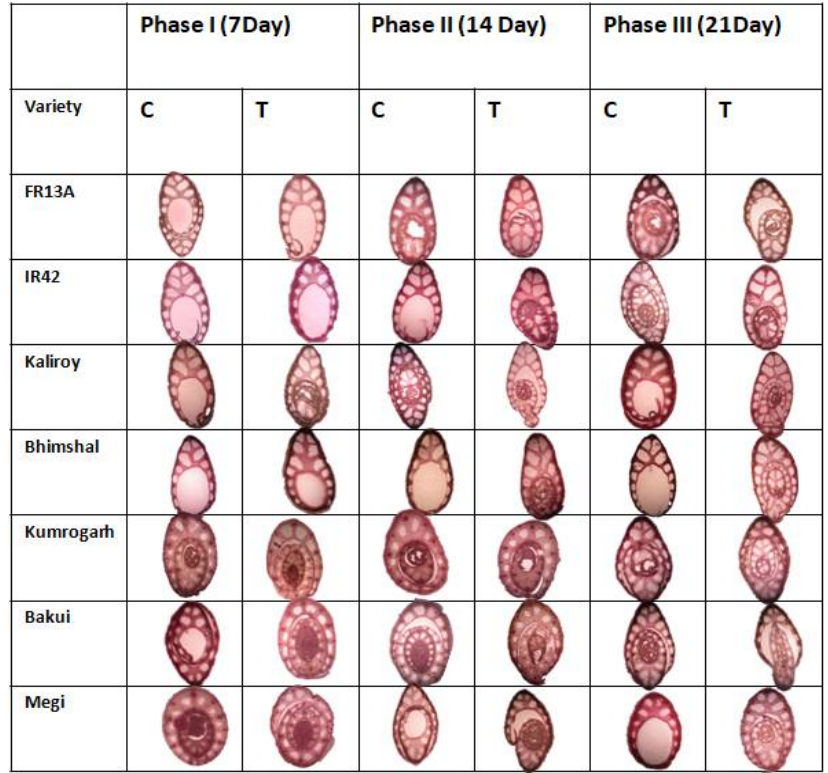

Fig. 8. Transverse section of $1^{\text {st }}$ internode of all genotypes for showing air cavity formation under water for 7,14 and 21 days at $90 \mathrm{~cm}$ water depth with control.

we measured the plant height from base to the longest leaf tip. But, leaf petiole or blade length was not measured. This increases the high lodging resistance, after flood water recedes, as increase in internode length is proportionately related to higher chance of lodging.

Anatomical variation unveiled development of air spaces in terms of \% of increased airspaces, at a greatest extent was in Kumrogarh after 14 day of submergence but was lowest after 21 days of submergence. Increase in total area of air spaces facilitates aerial respiration in Kumrogarh upto $14^{\text {th }}$ 


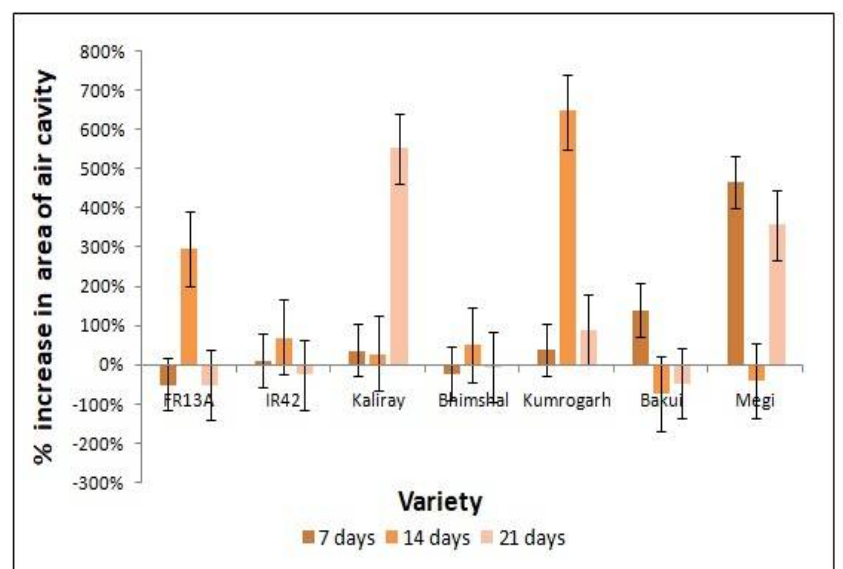

Fig. 9. Percent increase in air cavity formation in the studied genotypes.

day under water which also lowers lodging capacity after 21 days of submergence. As increase in air cavity formation reduces the mechanical strength of culm thus, prone to lodging after flood water recedes (24-26) and lodging subsequently causes pathogenic attack thus yield loss, so searching for a genotype with elongation growth behavior with lower development of aerenchyma tissue would facilitate may benefitted by reduced usage of nonhazardous chemicals and adapt flooding as weed control practice which will be environment friendly. Tolerance at early seedling stage increase the rate of survival and lastly, least air space formation and leaf blade elongation create little chances for lodging after desubmergece for Kumrogarh. As our main aim was to develop a robust cultivar having flood tolerance ability starting from germination to vegetative stage as flood may occur at any growth stages or may occur repeatedly at the same growing season in flood-prone areas. Kumrogarh performed outstandingly under deep water submergence from germination to mature stages. Only is need to identify the genetic factors or regulators and the probable pathways in which they intercept, critically for each stage submergence response, will pave the path for better understanding deep water stress property for Kumrogarh and for other varieties in future.

\section{Acknowledgements}

Financial assistance was provided by the Department of Science and Technology and Biotechnology, Govt.

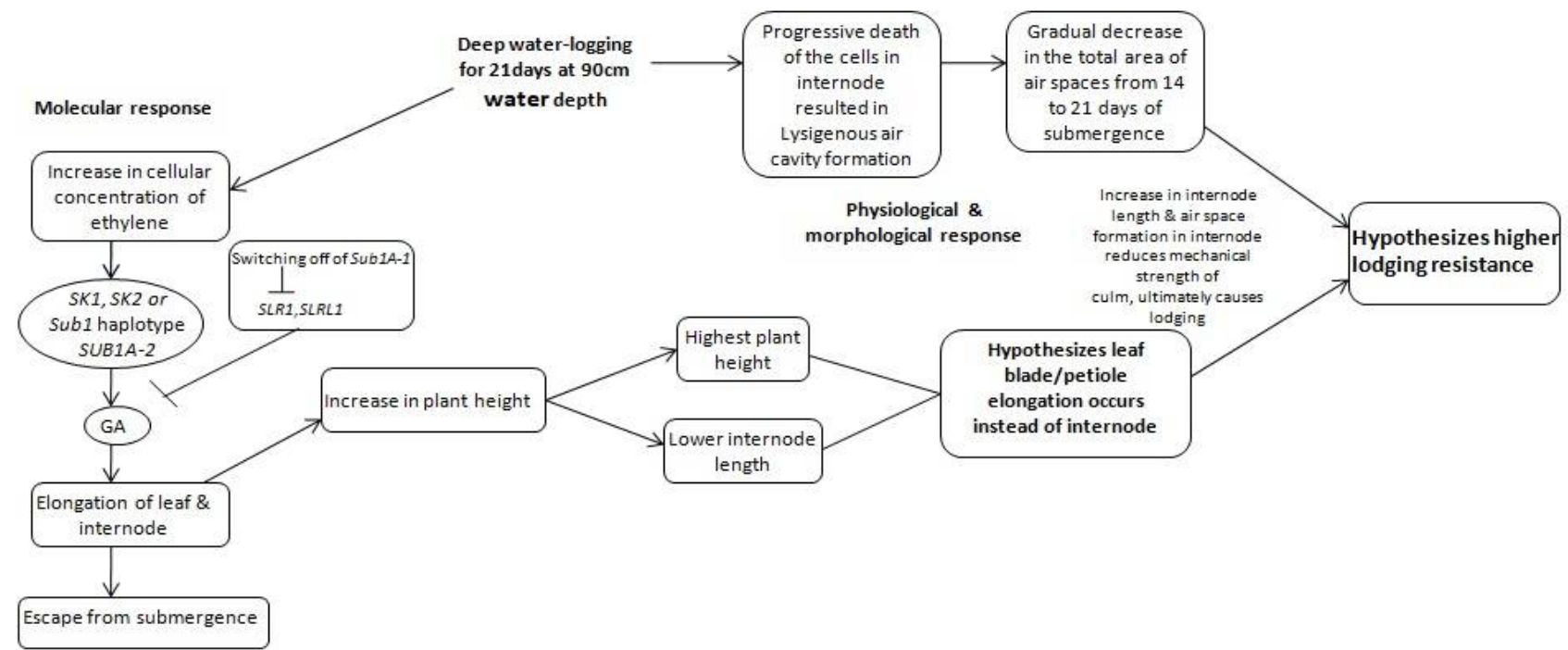

Fig. 10. A proposed model showing growth and development of rice plants under submergence with possible way of interaction of associated hormones involving both Sub 1 and SK loci.

prolonged survival without compromising yield loss.

\section{Conclusion}

By considering all the physiological and morphological parameters it can be concluded that Kumrogarh is the most promising genotype out of all studied varieties in deep flooded areas, thus, we have constructed a flow diagram featuring kumrogarh's growth behavior stating about its beneficial aspects in a diagrammatic presentation (Fig. 10) which will clearly discussed about its flood tolerance ability starting from germination to vegetative stage with involvement of Sub1 and $S K$ loci (data of Sub1 and $S K$ studied earlier, paper communicated). The present study illustrates not only anaerobic germination tolerance make easier the direct seeding practice for the growers but also of West Bengal in form a research project (Ref. No. 233(Sanc)/ST/P/S\&T/IG-75/2017), Infrastructure needed for conducting the experiments was provided by Visva-Bharati and PS received her fellowship from Visva-Bharati as UGC Non-NET fellow.

\section{Authors' contributions}

PS carried out the total work and drafted the manuscript. ND coordinated the study. AC provided the rice germplasm and performed agromorphological characterization.

\section{Conflict of interests}

Authors do not have any conflict of interests to declare. 


\section{Supplementary files}

Table 1. Morpho-physiological features measured and measuring unit.

Table 2. t-Test for two samples assuming unequal variances for different parameters for each stage. If $t$ stat $>$ tcrt, $p$ value $<0.05$, value is significant.

\section{References}

1. Singh A, Septiningsih EM, Balyan HS, Singh NK, Rai V. Genetics, physiological mechanisms and breeding of flood-tolerant rice (Oryza sativa L.) Plant Cell Physiol. 2017;58(2):185-97. https://doi.org/ 10.1093/pcp/pcw206

2. Huke RE, Huke EH. Rice Area by Type of Culture. South, Southeast, and East Asia. A Revised and Updated Database. International Rice Research Institute, Los Ban os, Philippines. 1997.

3. Bailey-Serres J, Voesenek LA. Life in the balance: a signalling network controlling survival of flooding. Curr Opin Plant Biol 2010;13:489-94. https://doi.org/10.1016/j.pbi.2010.08.002

4. International Rice Research Institute. Rice almanac, 2nd edn. Manila, Philippines: International Rice Research Institute. 1997;pp 181.

5. Mackill DJ, Ismail AM, Singh US et al. Development and rapid adoption of submergence-tolerant (Sub1) rice varieties. Adv Agronomy. 2012;115:299-52. https://doi.org/10.1016/B978-0-12 394276-0.00006-8

6. Jackson M, Ram PC. Physiological and molecular basis of susceptibility and tolerance of rice plants to complete submergence. Annals of Botany. 2003;9:227-41. https://doi.org/ 10.1093/aob/mcf242

7. Sarkar RK, Reddy JN, Sharma SG, Ismail AM. Physiological basis of submergence tolerance in rice and implications for crop improvement. Current Science. 2006;91:899-06.

8. Das KK, Panda D, Sarkar RK, Reddy JN, Ismail AM. Submergence tolerance in relation to variable floodwater conditions in rice. Environmental and Experimental Botany. 2009;66:425-34. https://doi.org/10.1016/j.envexpbot.2009.02.015

9. Ismail AM, Ella ES, Vergara GV, Mackill DJ. Mechanisms associated with tolerance for flooding during germination and early seedling growth in rice (Oryza sativa). Annals of Botany. 2009;103:197-09. https://doi.org/10.1093/aob/mcn211

10. Bailey-SerresJ, Fukao T, Ronald P C, Ismail AM, Heuer S, Mackill DJ. Submergence tolerant rice: SUB1's journey from landrace to modern cultivar. Rice. 2010;3:138-47. https://doi.org/10.1007/s12284-010- 9048-5

11. Ismail AM, Johnson DE, Ella ES, Vergara GV, Baltazar AM. Adaptation to flooding during emergence and seedling growth in rice and weeds and implications for crop establishment. AoB PLANTS. 2012;pls019.https://doi.org/10.1093/aobpla/pls019

12. Magneschi L, Perata P. Rice germination and seedling growth in the absence of oxygen. Ann Bot. 2009;103:181-96. https://doi.org/ 10.1093/aob/mcn121

13. Miro B, Ismail AM. Tolerance of anaerobic conditions caused by flooding during germination and early growth in rice (Oryza sativa L.). Front Plant Sci. 2013;4:269 https://doi.org/10.3389/fpls.2013.00269

14. Balasubramanian V, Hill JE. Direct seeding of rice in Asia: emerging issues and strategic research needs for the 21st century. In: Pandey S, Mortimer M, Wade L, Tuong TP, Lopez K, Hardy B (eds). Direct seeding: research strategies and opportunities. Los Ban os, Philippines: International Rice Research Institute. 2002;15-39.
15. Estioko LP, Miro B, Baltazar AM, Merca FE, Ismail AM, Johnson DE. Differences in responses to flooding by germinating seeds of two contrasting rice cultivars and two species of economically important grass weeds. AoB PLANTS. 2014;6:plu064. https://doi.org/10.1093/ aobpla/plu064

16. Kawano R, Doi K, Yasui H, Mochizuki T, Yoshimura A. Mapping of QTL for floating ability in rice. Breed Sci. 2008;5:47-53. https://doi.org/10.1270/jsbbs.58.47

17. Catling D. Rice in Deep Water. MacMillan Press, London; 1992. https://doi.org/10.4236/jwarp.2016.86054

18. Miro B, Longkumer T, Entila FD, Kohli A, Ismail AM. Rice seed germination underwater: morpho-physiological responses and the bases of differential expression of alcoholic fermentation enzymes. Front Plant Sci. 2017;8:1857. https://doi.org/10.3389/fpls.2017.01857

19. Huang SB, Greenway H, Colmer TD. Anoxia tolerance in rice seedlings: exogenous glucose improves growth of an anoxia-'intolerant', but not of a 'tolerant' genotype. Journal of Experimental Botany. 2003;54:2363-73. https://doi.org/10.1093/ jxb/erg252

20. Alpi A, Beevers $\mathrm{H}$. Effects of $\mathrm{O} 2$ concentration on rice seedlings. Plant Physiology. 1983;71:30-34. https://doi.org/ 10.1104/pp.71.1.30

21. Kawai M, Uchimiya H. Coleoptile senescence in rice (Oryza $\begin{array}{llll}\text { sativa } & \text { L.). Ann 2000;58:405-14. }\end{array}$ https://doi.org/10.1006/anbo.2000.1199

22. Angaji SA, Septiningsih EM, Mackill DJ, Ismail AM. QTLs associated with tolerance of flooding during germination in rice (Oryza sativa L.). Euphytica. 2010;172:159-68. https://doi.org/ 10.1007/s10681-009-0014-5

23. Vu HTT, Nguyen GT, Nguyen TT, Vo TTM, Nakamura C. Contribution of seedling vigour and anoxia/hypoxiaresponsive genes to submergence tolerance in Vietnamese lowland rice (Oryza sativa L.), Biotechnology and Biotechnological Equipment. 2016;30(5):842-52. https://doi.org/ $10.1080 / 13102818.2016 .1204944$

24. Das KK, Sarkar RK, Ismail AM. Elongation ability and nonstructural carbohydrate levels in relation to submergence tolerance in rice. Plant Sci. 2005;168:131-36. https://doi.org/10.1016/j.plantsci.2004.07.023

25. Kawano N, Ito O, Sakagami J. Morphological and physiological responses of rice seedlings to complete submergence (flash

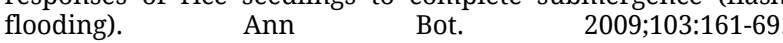
https://doi.org/10.1093/aob/mcn171

26. Kato Y, Collard BCY, Septiningsih EM, Ismail AM. Physiological analyses of traits associated with tolerance of long-term partial submergence in rice. AoB Plants. 2014;6, p. plu058. https:// doi.org/10.1093/aobpla/plu058

\section{Additional information}

Peer review information: Plant Science Today thanks Sectional Editor and the other anonymous reviewers for their contribution to the peer review of this work.

Reprints and permissions information is available at https://horizonepublishing.com/journals/index.php/PST/open_access_policy

Publisher's Note: Horizon e-Publishing Group remains neutral with regard to jurisdictional claims in published maps and institutional affiliations.

To cite this article: Samanta P, Chakrabarti A, Dey N. Varied shoot growth in rice plants across different developmental stages under induced flooding. Plant Science Today. 2021;8(3):704-711. https://doi.org/10.14719/pst.2021.8.3.1186

Plant Science Today, published by Horizon e-Publishing Group, is covered by Scopus, Web of Science, BIOSIS Previews, Clarivate Analytics, etc. See https://horizonepublishing.com/journals/index.php/PST/indexing_abstracting 